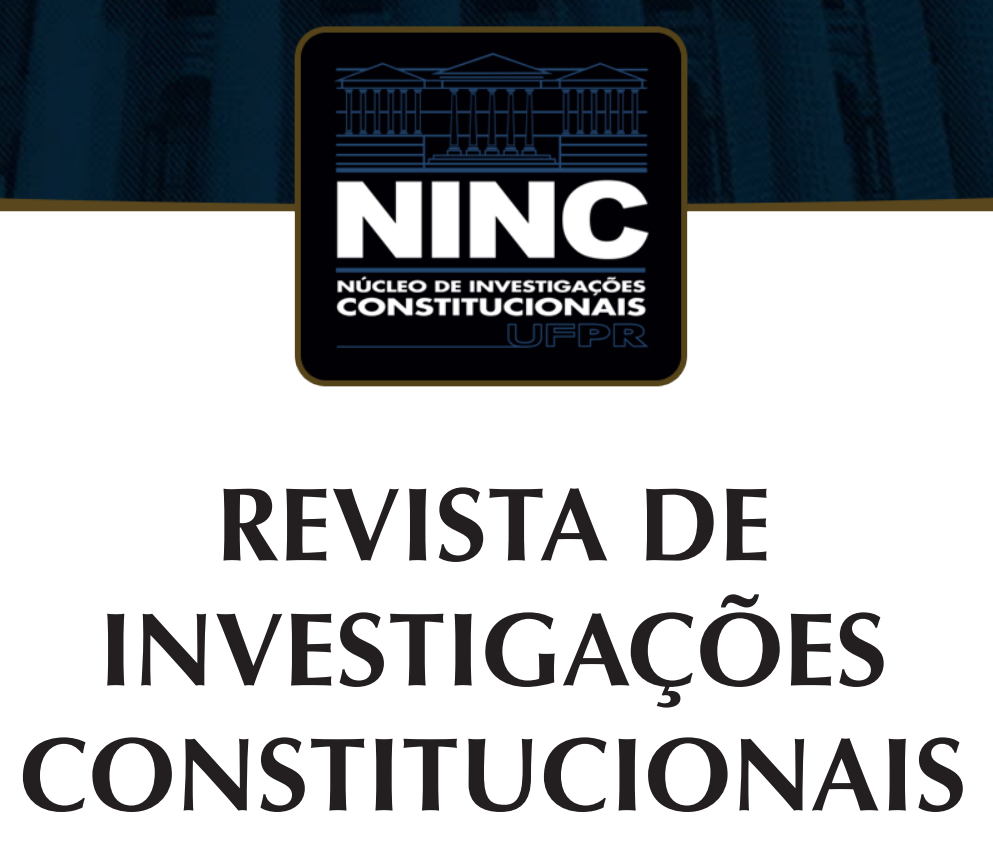

JOURNAL OF CONSTITUTIONAL RESEARCH

vol. 7 | n. 3 | setembro/dezembro 2020 | ISSN 2359-5639 | Periodicidade quadrimestral Curitiba | Núcleo de Investigações Constitucionais da UFPR | www.ninc.com.br 


\title{
The inexorableness of constitutional amendments and its democratic potentiality
}

\section{A inexorabilidade das emendas constitucionais e sua potencialidade democrática}

\author{
ANTONI ABAT NINET ${ }^{1, *}$ \\ ' Hebrew University of Jerusalem (Jerusalem, Israel) \\ antoni.abat@mail.huji.ac.il \\ https://orcid.org/0000-0002-1091-0820 \\ Recebido/Received: 06.05.2020 / May $6^{\text {th }}, 2020$ \\ Aprovado/Approved: $17.10 .2020 /$ October $17^{\text {th }}, 2020$
}

\begin{abstract}
Constitutional law and Democracy are two domains that are inevitably in tension. Nevertheless, there have been theories and proposals to improve the necessary coexistence of both elements in modern constitutional democratic systems. Richard Albert's work distinguishes between constitutional changes (amendments and dismemberments) and introduces a non-merely symbolic role to the people in terms of legitimacy, can be qualified as one of these theories. This paper focuses on the democratic input that Albert proposes along with his book.
\end{abstract}

Keywords: constitutional amendments; constitutional dismemberments; democracy; constitutional moments; derivate constituent power.
Resumo

O direito constitucional e a democracia são dois domínios que estão inevitavelmente em tensão. No entanto, tem havido teorias e propostas para melhorar a necessária coexistência de ambos os elementos nos sistemas democráticos constitucionais modernos. O trabalho de Richard Albert distingue entre mudanças constitucionais (emendas e desmembramentos) e introduz um papel não meramente simbólico para o povo em termos de legitimidade, podendo ser qualificado como uma dessas teorias. Este artigo enfoca a contribuição democrática que Albert propõe junto com seu livro.

Palavras-chave: emendas constitucionais; desmembramentos constitucionais; democracia; momentos constitucionais; poder constituinte derivado.

Como citar esse artigo/How to cite this article: ABAT NINET, Antoni. The inexorableness of constitutional amendments and its democratic potentiality. Revista de Investigações Constitucionais, Curitiba, vol. 7, n. 3, p. 689-705, set./dez. 2020. DOI: $10.5380 /$ rinc.v7i3.73540.

"Visiting Professor at the Faculty of Law at the Hebrew University of Jerusalem (Jerusalem, Israel). PhD at the Universitat de Barcelona (Barcelona, Spain). E-mail: antoni.abat@mail.huji.ac.il. 


\section{CONTENTS}

1. Inexorableness of constitutional amendments, 2. Democracy and constitutional amendments,

3. Unamendability and the democratic principle, 4. Reconciliation, 5. Constitutional Moments, Extraconstitutional and Popular amendments, $\mathbf{6}$. The People and the limits of the pouvoir constituant dérivé in relation to constitutional amendments and dismemberments, 7. Conclusion; 8. References.

\section{INEXORABLENESS OF CONSTITUTIONAL AMENDMENTS}

One of the most ancient philosophical controversies that we are aware of is the one between Heraclitus and Parmenides on the being of nature (physis). Heraclitus contended that everything flows and therefore, it is in a constant change, everything is dynamic and temporary. ${ }^{1}$ In constitutional terms, no constitution is permanent, and of course, no disposition is unamendable. Constitutions are continually flowing throughout a never-ending change. If we consider that constitutional amendments give form and path to this constant change, then we will support Richard's claim, constitutional amendments are an essential part of constitutions, not only procedurally but also materially. ${ }^{2}$

On the other hand, we can also conceive the opposite, constitutional amendments are mostly irrelevant, ${ }^{3}$ because constitutional change is inexorable, and it would happen no matter what the constitutional provisions on the amendment may stipulate. In this case, the role of the amendment is limited, in the best-case scenario, to juridify changes that already occurred. The change produces the amendment rather than the other way around. ${ }^{4}$

In front of Heraclitus, we find Parmenides who considered that nothing changes, and any change is always illusionary. Change is impossible and irrational. Reason (Logos) dictates what is real and what is not, and according to the famous quotation of Parmenides: "whatever is, is, and what is not cannot be".

It is remarkable that according to the monist interpretation of Parmenides, the only reason establishes the being. The same "reason" and rationalisation that involves law. Law, modern law, is exclusively rationality, reason, and its legitimacy lies solely in axioms of legal rationalism. In this sense, a possible interpretation of Parmenides words

1 CONCHE, Marcel. The Fragments of the Work of Heraclitus of Ephesus On Nature. London: Creative Media Partners, 2018.

2 ALBERT, Richard. Constitutional Amendments: Making, Changing and Breaking Constitutions. New York: Oxford Univ. Press, 2019.

3 See STRAUSS, David. A. The irrelevance of constitutional amendments. Harvard Law Review, vol. 114, p. 1457-1505, 2001.

4 STRAUSS, David. A. The irrelevance of constitutional amendments. Harvard Law Review, vol. 114, p. 1457$1505,2001$.

5 GALLOP, David. Parmenides of Elea: Fragments, a Text and Translation. Toronto: Toronto University Press, 1984 
in our domain would be that only law, as pure reason determines what is real, meaning, that only codified (rationalised norms) can be qualified as amendment rules.

It is not plausible to understand the process of amendment as aseptic and straightforward transplantation of social or political changes into the realm of law. The process of juridification considered as a defining element of the rule of law it is also an element to enforce rationalisation. Constitutional amendments (codified or not) implies a process of (legal) rationalisation, and even considering an amendment as simply ratifying of changes that have already take place in society, the process of juridification has not only normative effects but also material ones. Therefore, it may also affect the change that causes the amendment process.

As a matter of example of this ancient debate in constitutions, constitutionalism and amendments, we can questioning whether the Constitution of Egypt of 2014 has changed the previous Constitution of 30 November 2012? Both constitutions are results of revolutionary and counter-revolutionary événements. ${ }^{6}$ Then an obvious presumption is to think that both constitutional drafts involved significant changes in political and constitutional terms.

The Constitution of 2012 was passed by an Islamist party (Muslim Brotherhoods) that constitutionalised the main goals of the revolution (building up a democratic state, adherence to democratic principles, pluralism and multiparty system). However, the previous Constitution of 1971 in force under the Presidency of Hosni Mubarak already stated that Egypt was a democratic state (art.1), with a multiparty system (art.5). In addition, the current Constitution of 2014 recognises these principles, democratic Republic (art.1), with a political system based on political and partisan multiplicity (art.5). Perhaps due to a sort of constitutional "inertia" and despite the political measures that Mubarak, Morsi (potentially) and Sisi implemented, to eliminate these dispositions have a higher cost than to behave accordingly to them.

The reading of article 2 (as amended in 1980) of all these constitutional charters, the one related to the role of Islam and Sharia, a disposition exported by Egypt to the rest of the Arab world, can also enlighten the real change that these revolutions have caused in constitutional terms. Certainly, we can also define these dispositions as aspirational constitutionalism, ${ }^{7}$ or "programmatic" constitutional declarations because of its null incidence in the daily life of citizens, as Chapter 1 of the book analyses in the section "Text and Reality".

\footnotetext{
6 RICOEUR, Paul. Événement et sens. Raisons practiques, vol. 2, p. 41-56, 1991.

7 SCHEPELLE, Kim Lane. Aspirational and Aversive constitutionalism: The case for studying cross-constitutional influence through negative models. International Journal of Constitutional Law, vol. 1, n. 2, p. 296324, 2003.

8 ALBERT, Richard. Constitutional Amendments: Making, Changing and Breaking Constitutions. New York: Oxford Univ. Press, 2019. p. 51.
} 
The answer to these questions is related to a more essentialist analysis on constitutions. Additionally, no constitution can stop a revolution, a military coup and another kind of political events, neither a constitutional amendment can. Richard acknowledges this Realpolitik truism from a constitutional perspective by saying: "if the political will exists to alter an obdurate constitutional text, a new constitution can be written with the unamendable rule removed or loosened". ${ }^{\prime}$ Not even a new constitutional text is essential, and: "where constitutional replacement is impossible....the authoritative interpreter may find a way to interpret a constitutional amendment", ${ }^{10}$ or a constitutional disposition. This fact is even more flagrant because no constitutional system escapes of direct or indirect control of the executive branch and partycracy. ${ }^{11}$

However, from a pragmatic perspective, despite whether we may consider amendments as irrelevant or the most critical section of our constitutions, constitutional amendments are a normative and a material reality that cannot be detached of constitutional charters. From a Kantian pragmatic perspective or a strict positivistic standpoint, there cannot be a constitution without "rules for changing the rules".12 There is no constitution without amendment rules. An objective fact that per se justifies, Richard Albert's insight in this magnificent book and reinforces the centrality that amendments have in comparative constitutional law. ${ }^{13}$

\section{DEMOCRACY AND CONSTITUTIONAL AMENDMENTS}

A reader influenced by the Critical Legal Studies approaches the relation of law and Democracy with scepticism or even nihilism. Law implies rationalisation and social domination and consequently is not easy to fuse with democracies. The use of the euphemism "constitutional democracies" instead of mixed governments to define our "democratic" political systems is not improving the relation between the two elements of the paraphrase.

However, the way that Albert links constitutional amendments and Democracy is compelling and opens paths to develop popular participation in the realm of

\footnotetext{
9 ALBERT, Richard. Constitutional Amendments: Making, Changing and Breaking Constitutions. New York: Oxford Univ. Press, 2019. p. 141.

10 ALBERT, Richard. Constitutional Amendments: Making, Changing and Breaking Constitutions. New York: Oxford Univ. Press, 2019. p. 141.

11 COTA, Maurizio. Partitocracy: Parties and their Critics in Italian Political Life. In: PASQUINO, Jones, E., (eds.). The Oxford Handbook of Italian Politics. Oxford-New York: Oxford University Press, 2015. p. 41-52.

12 ALBERT, Richard. Constitutional Amendments: Making, Changing and Breaking Constitutions. New York: Oxford Univ. Press, 2019. p. 3.

13 TUSHNET, Mark. Peasants with Pitchforks, and Toilers with Twitter: Constitutional Revolutions and the Constituent Power. International Journal of Constitutional Law, vol. 13, n. 3, p. 639-654, 2015.
} 
constitutionalism. Whether this is a romantic form, ${ }^{14}$ does not change its potentiality, especially in a society where digital technologies are applicable. However, there is also a question related to the essential nature of the amendment and its legitimacy; an epistemological question, that Richard responses excellently: "The right to amend a constitution is above all a right to democratic choice. Amendment rules, then, shall be designed and used for a related reason: to promote democracy". ${ }^{15}$ Albert continues quoting Rubenfeld to remark that written constitutionalism requires a process of popular writing and re-writing.

I would add that not only written constitutionalism, also non-written constitutionalism using non-codified means requires processes to enable the participation of the people in the amendment of the non-codified but constitutional norms. Nowadays only three state constitutional systems around the world are classified as "non-written" (United Kingdom, Israel and New Zealand) a disputed definition, because not codified in a single text, does not mean unwritten. ${ }^{16}$

Can a non-codified constitutional amendment serve formal, functional and symbolic uses in constitutionalism? In non-codified constitutionalism, amendments are also inexorable, and if the system is defined as democratic, it needs to involve the Demos in constitutional matters.

As Richard Albert has observed, the practice of unamendability plays a critical role in the relation between constitutional amendment and democracy (chapter 4 and p.271). As he notes, to limit the possibility of constitutional change is not a reasonable option in the modern world, and it would lack legitimacy of present popular consent. ${ }^{17}$ Even that these limits to amend affect matters such as the bill of rights, peace (Japanese Constitution), republican form (French Constitution) or human dignity (German Constitution).

Besides, I believe that the inclusion of these kinds of constitutional dispositions does not make sense because of the inexorability of the change (Heraclitus) and the fact that no constitutional disposition can prevent a revolution, some political changes or constitutional moments (Ackerman). Consider the political debate opened in Japan, where Prime Minister Shinzo Abe attempted to amend Article 9 of the Japanese Constitution. With this article, Japan renounces war as a sovereign right and the threat of use of force as a mean of settling international disputes and prohibits the maintenance of

\footnotetext{
14 STRAUSS, David. A. The irrelevance of constitutional amendments. Harvard Law Review, vol. 114, p. 14571505, 2001.

15 ALBERT, Richard. Constitutional Amendments: Making, Changing and Breaking Constitutions. New York: Oxford Univ. Press, 2019. p. 46.

16 GREY, Thomas. C. Origins of the Unwritten Constitution: Fundamental Law in American Revolutionary Thought. Stanford Law Review, vol. 30, n. 5, p. 843-893, 1978.

17 ALBERT, Richard. Constitutional Amendments: Making, Changing and Breaking Constitutions. New York: Oxford Univ. Press, 2019. p. 271.
} 
land, sea and air forces. Some authors consider the Prime's Minister proposal and the use of a specific referendum on the topic, as a constitutional coup; ${ }^{18}$ others an unconstitutional constitutional amendment. ${ }^{19}$

On the other hand, some authors argue that article 9 contradicts Japan's place in the contemporary world and the factual reality. Despite the strong symbolic character of the article and its conceptualisation as a Japanese (imposed) constitutional value of peace, Japan has the fourth largest military in the world. Therefore, we find again here a question of text and reality and assertive and aspirational principles.

A second example on the inexorability of change and the relative transcendence of constitutional dispositions and amendments in front of some political events is the null constitutional changes that the independence of Algeria caused in the French Constitution of the Fifth Republic of 1958. The process of independence of the French dépaterments in Algeria caused constitutional crises the ended with the Fourth Republic and the Constitution of 1946. A constitutional text that for the first time in French history consecrated the complete equality of rights between the citizens of metropolitan France and those of overseas.

However, the independence occurred in 1962, four years later, the enactment of the current constitution, and not constitutional amendment happened in the text. Alternatively, as Diemert explains, from the entry into force of the Constitution of 4 October 1958 until the mid-1970s, the overseas territories were progressively marginalised and normalised on the constitutional level, the secession of Algeria takes place in a legal context marked by the almost complete absence of constitutional review. ${ }^{20}$

\section{UNAMENDABILITY AND THE DEMOCRATIC PRINCIPLE}

Richard Albert is bright on the democratic inconvenient that non-amendable provisions cause. The conclusion of the book is an example of the significance that this aspect has for the author. In the introduction of Chapter 4, after explaining the Zelaya's affair in Honduras, he concludes stating: "But should Hondurans have been denied the right to speak their views on an issue so central to their political life? It is, after all, their constitution, and they are the ones who must live it with it".21 This thoughtful statement re-

\footnotetext{
18 ACKERMAN, Bruce; MATSUDAIRA, Tokujin. Dishonest Abe. Foreign Policy, 24 June 2014. Available at: $<$ http://foreignpolicy.com/2014/06/24/dishonest-abe/>.

19 ROZNAI, Yaniv. Unconstitutional Constitutional Amendments: The Limits of Amendment Powers. Oxford: Oxford University Press, 2017.

20 DIEMERT, Stephane. L'histoire constitutionnelle de l'outre-mer sous la Ve République. Nouveaux Cahiers du Conseil Constitutionnel, Paris, n. 35, Dossier: La Constitution et I'Outre-Mer, avr. 2012. Available at: $<$ https://www.conseil-constitutionnel.fr/nouveaux-cahiers-du-conseil-constitutionnel/I-histoire-constitutionnelle-de-l-outre-mer-sous-la-ve-republique>.

21 ALBERT, Richard. Constitutional Amendments: Making, Changing and Breaking Constitutions. New York: Oxford Univ. Press, 2019. p. 140.
} 
flects the issues that unamendability also inflects to the fundamental rights of political participation and freedom of speech.

Besides the good reasons that Albert remarks, there are additional problems of unamendable constitutional dispositions from a democratic perspective. Such as who decides what is unamendable, when it does so, and what for. The answers to these questions, in constitutional democracies, must be democratically legitimate.

Following the three varieties of unamendability (codified, interpretative and constructive), the one who decides, who is acting as a sovereign (Theorie des Dezisionismus) in the first case, is an elected body with the exceptions of illiberal democracies and imposed governments. In the second category (interpretative unamendability), the decision is taken by an unelected body, the judiciary (with some exceptions of legislature possessing powers of binding constitutional interpretation). Within this category, mixed bodies exercising the control of constitutionality, such as the Conseil Constitutionnel (France, Lebanon, Cameroun) may be included. In the third case (constructive), the decision-makers are political actors also selected democratically.

All classification involves elements of subjectivity, this one presented by Richard Albert includes a hybrid category (constructive unamendability) that can also be defined as deconstructive in a Derridian sense, a codified procedure of amendment, the decision can be taken by both, elected and unelected bodies.

Even that the dominant view, ${ }^{22}$ considers that judicial invalidation of constitutional amendments rests on democratic foundations, the tensions with the principle of Democracy are obvious since the landmark case Marbury v. Madison, as Jefferson already pointed out and has given rise to much debate and caused rivers of ink to flow.

Richard Albert starts his account on this topic by summarising Yaniv Roznai's "contractual" theory, where the "people authorises" the constituted powers, to act in her name. It follows by remarking that according to another understanding of constitutional change, the doctrine of unconstitutional amendment denies democratic choice to reformers and the people. ${ }^{23}$ Then, Albert takes a kind of Pontius Pilate's position: "whether democracy demands the doctrine of unconstitutional amendment depends on one's view of what democracy requires". ${ }^{4}$ Certainly, "democracy" is a concept that has had multiple meanings throughout history. Today it is still a vague concept. Democracy can be understood as a principle, as a political orientation of those who favour government by the people. Democracy appears to mean popular, political self-government - the

\footnotetext{
22 ALBERT, Richard. Constitutional Amendments: Making, Changing and Breaking Constitutions. New York: Oxford Univ. Press, 2019. p. 217.

23 ALBERT, Richard. Constitutional Amendments: Making, Changing and Breaking Constitutions. New York: Oxford Univ. Press, 2019. p. 221.

24 ALBERT, Richard. Constitutional Amendments: Making, Changing and Breaking Constitutions. New York: Oxford Univ. Press, 2019. p. 271.
} 
people of a country deciding for themselves the contents (especially, one would think, the most fateful and fundamental contents) of the laws that organise and regulate their political association.

There is a common observation that constitutionalism and Democracy are inevitably in tension. Democracy seems to require that the current policy judgements of today's majority be implemented, while constitutionalism seems to require that some such judgements be thwarted. Constitutionalism appears to mean the containment of popular political decision making by a basic law, the constitution.

If there is no a link between the people and the constitution the relations become antithetical because the elite deciding in the name of the people becomes a sort of modern oligarchy which consolidates an institutional structure mirroring the socioeconomic classes. Demos and Democracy will be the poor class and constitutionalism and the decider will be represent the economic and politic elites. The antithetical character of these concepts does not exclude the possibility of mediation between them, and this is where constitutional amendments as conceived by Richard Albert in the book shall play an important role.

\section{RECONCILIATION}

Chapter 4 includes "reconciliation" among the different uses of codified unamendability. This kind of non-amendable constitutional provisions aim to end a conflict between previously conflicting groups. Richard Albert follows by stating: "unamendability as reconciliation makes peace possible between enemies conferring irrevocable amnesty for prior conduct.....The new constitutions of Niger and Ghana granted eternal immunity to the architects, enablers, and executors of these destructive episodes in the life of each country".25

If this is a normative claim, we need to observe other transitions to Democracy from regimes of horror to have the complete picture. For example, the effects of the lack of transitional justice in Spain causes that after 40 years of the death of the dictator, more than 140.000 persons are disappeared in mass graves without exhumation, trial, reparation or justice. Despite Ghana struck an agreement to create an innovative ceasefire constitution, the constitutionalisation of this kind of amnesty laws and "reconciliation acts" is undemocratic and in some cases breaches international humanitarian law. The unamendable form of these dispositions deters any transitional justice or reparation from the superior legal norm of the country.

Legislators are well-aware that this amnesty dispositions breach the principle of universal jurisdiction, the enforcement of jus cogens and erga omnes obligations and

25 ALBERT, Richard. Constitutional Amendments: Making, Changing and Breaking Constitutions. New York: Oxford Univ. Press, 2019. p. 143. 
prevent the prosecution of crimes against humanity, war crimes, genocide, and torture. In this sense, the Rome statute (signed and ratified by Ghana) grants the international foundation that strengthens the domestic enactment of acts and the engagement of the judiciary to handle cases that offend humanity in general irrespective of their location or residence.

Therefore, there is not only a democratic requirement of unamendability; there are also human rights and human dignity requirements to be fulfilled. ${ }^{26}$ In Ghana, the constitutional unamendability has caused a legal loophole making the country potential safe havens for fugitives suspected of war crime and crimes against humanity (Amnesty International). Ghana, as in Spain, can face a legal paradox, genocide can be prosecuted except if it was committed by a Ghanaian.

The book proposes alternatives to codified unamendability consisting in "offer its expressive benefits without democratic burdens....codifying an escalating structure of restricted amendment pathways to make some constitutional rules harder to amend than others yet without insulating any of them from formal change". ${ }^{27}$ This escalating structure may incorporate several degrees of amendment difficulty designating different thresholds (the highest threshold applied to the essential features of the constitution) and including the participation (in composed or federal states) of the subnational legislatures. As Richard Albert states, this escalate structure offers the benefits of unamendability while no extinguishing the power of amendment. ${ }^{28}$

Albert's proposal is coherent with the democratic principle because the organs in charge to decide on the amendability of a constitutional disposition are representatives elected by the people. However, if the constitutional control stills been attributed to the judiciary, a non-elected body will continue to have the power of decision on the formal and material elements of the norm (including its amendability).

The escalating structure erases the symbolism and political connotations that the status of unamendability involves. Legislators defining as "unamendable" a constitutional principle or disposition aim to determinate a concrete political and legal behaviour of citizens and public officers. In some of the cases, constitutional unamendability is the first stone of political culture and constitutional identity principle. Take the principle of human dignity in Germany as an example of this. The state needs the coercion that the declaration of unanmendability implies to impose concrete social and political

\footnotetext{
26 ALBERT, Richard. Constitutional Amendments: Making, Changing and Breaking Constitutions. New York: Oxford Univ. Press, 2019. p. 198-202.

27 ALBERT, Richard. Constitutional Amendments: Making, Changing and Breaking Constitutions. New York: Oxford Univ. Press, 2019. p. 201.

28 ALBERT, Richard. Constitutional Amendments: Making, Changing and Breaking Constitutions. New York: Oxford Univ. Press, 2019. p. 202.
} 
behaviour. It is a crude act of sovereignty, dominion and legal rationalisation of the real constituent power and not the figurative one.

With his proposal I wonder whether Richard Albert accepts a sort of constructive unamendability for the essentials features of the constitution, "a constitutional norm is constructively unamendable when the codified threshold required to amend it are so onerous that reformers cannot realistically satisfy the standard ..... requiring reformers to perform impossible heroics to successful amend the constitution".29

Do democratic constitutional systems necessarily need non-amendable dispositions to protect their meta-constitutional values, principles and identity? If Albert believes so, no escalating structure is required. If the unamendability is to protect the essential requirements for a democratic state (as in the case of the Czech Republic), we are in front of a democratic paradox, if there is a democratic agreement on these essential requirements.

\section{CONSTITUTIONAL MOMENTS, EXTRACONSTITUTIONAL AND POPULAR AMENDMENTS}

The introduction of the book defines the theory of Constitutional Moments of Bruce Ackerman comparing it with the basic structure doctrine of the Indian Supreme Court. Richard Albert considers that these theories resemble, both have altered how the constitution is changed, and when we recognise a change as valid. He contends correctly that: "a constitutional moment is not just any profound transformation in constitutional meaning... it is a precedential change to formal amendment rules without a formal amendment. At bottom, a constitutional moment is a successful reconfiguration of the process and political consensus required to legitimate a constitutional change". Albert then remarks the powerful implication that the theory has retelling that codified rules of change can themselves de changed without a corresponding recodification".30

The theory of constitutional moments deserves more attention when talking about constitutional amendments. Despite I believe that the name "constitutional moments" is not accurate, because Ackerman defines these "moments" as processes that happen progressively and not in a concrete instant.

As described by Ackerman, constitutional moments occur very rarely (only three times in the history of the U.S), at times when "We the People" speak using extraconstitutional means to make fundamental changes in the constitution. The fact that they are "extraconstitutional" and "popular" at origin is also remarkable and transcendent to the

29 ALBERT, Richard. Constitutional Amendments: Making, Changing and Breaking Constitutions. New York: Oxford Univ. Press, 2019. p. 158-159.

30 ALBERT, Richard. Constitutional Amendments: Making, Changing and Breaking Constitutions. New York: Oxford Univ. Press, 2019. p. 22. 
relations of constitutional amendments and Democracy. The relevance is evident because the initiator of the constitutional change is the people themselves, and it shows, that there are extraconstitutional ways to amend the constitution; without the need to follow the legal processual formalities and even the material limitation.

Constitutional moments are characterised by the fact that an unusually high number of citizens are convinced of the seriousness of the matter under discussion (far greater than in the case of decisions to be taken in normal times), by the fact that all citizens have the opportunity to express their views on the question, and finally by the fact that a majority supports a specific way of solving the question. ${ }^{31}$

Richard Albert's explanation of these particular moments lacks an important element, the epistemological relation that the constitutional moments have with the normal politics. Ackerman defines both concepts in a dialogical way; we cannot conceive a constitutional moment without normal politics. As we cannot understand the definition of constitutional dismemberment deprived of constitutional amendments. The distinction between normal and constitutional moments turns out to be mapped onto each other.

In normal politics, we include the everyday decisions taken by the government; there is no debate or popular mobilisation. The electorate entrusts the management of legal matters to the government, and the government, legitimated by this mandate, takes the decisions that it believes most appropriate. In normal politics, a "united" population allows democratically. Normal moments are managed by elected representatives, while constitutional moments are managed by the people; normal politics are not particularly reflective, whereas constitutional politics are; normal politics involve the pluralist pursuit of group interests, while constitutional politics involve principles and the common good. ${ }^{32}$

A constitutional moment also plays a role in altering the framework in which normal politics develop: That is, constitutional moments not only differ from the periods of normality that precede and follow them but must also ensure that the two phases of normal politics, before and afterwards, are different. Even that constitutional moments are infrequent, occurring only at key political moments; they have long-lasting constitutional effects (even though the constitutional moment is only temporary) and, most importantly for the present paper, the citizens who aim to effect a constitutional transformation act directly.

For Ackerman, we should treat normal moments - that is, the situation in which the people decide to withdraw from politics - with the greatest respect. The people delegate power to their representatives, who may be substituted through the appropriate

\footnotetext{
31 See ACKERMAN, Bruce. We the people Foundations. Cambridge: Harvard University Press, 1995.
}

32 HERZOG, Donald J. Democratic Credentials. Ethics, vol. 104, n. 3, p. 467-479, 1994. 
democratic procedures. Therefore, normal politics is as important as constitutional politics for the stability and necessary continuity that every legal system needs. As noted above, the purpose of the constitutional moment is to affect a specific normal moment in a direct way and to produce a different new normal moment.

The theory and experience of constitutional and normal moments should be studied when proposing a constitutional amendment theory, which stimulates a democratic role in the process of constitutional change. Since in this theory, citizens have direct access to the promulgation of the fundamental laws of their state, without intermediaries.

However, the study of how "the people" act directly in constitutional amendments should be adapted within the types of amendments categorised in the book. This differentiation will help us to understand that the dialogue among citizens will vary according to the type of amendment, the political context, time and society.

\section{THE PEOPLE AND THE LIMITS OF THE POUVOIR CONSTITUANT DÉRIVÉ IN RELATION TO CONSTITUTIONAL AMENDMENTS AND DISMEMBERMENTS}

One of the most important contributions of Richard Albert's book to constitutional doctrine is his distinction between constitutional amendments and constitutional dismemberments. The difference is structured in four techniques, procedural, narrow textual approach (positivist) and consent-based approach. The notion of dismemberment is a precious doctrinal response to a phenomenon that had not a theoretical autonomous accommodation, but it happened the de facto.

A constitutional change targeting the essential characteristics of the constitution, the constitutional identity principles, or to destroy the constitutional foundation cannot be considered as a simple amendment. The distinction provides a theoretical response to a phenomenon that differs from constitutional changes because it affects the fundamental ontology of the constitution, its Being. ${ }^{33}$

The chapter grounds the distinction of amendment and dismemberment from Carl Schmitt's theory of constitutional change, and the difference between pouvoir constituant (constituent power) and pouvoir constitué (constituted power) of Joseph Sieyès. Albert follows Sieyès' hierarchical division of labour between the people, as principals, and their agent representatives in government. The superior group is the constituent power referring to the body of "people" (as constitutional fictional construction) in whom supreme power resides. The inferior group is the constituted power as the

33 HEIDEGGER, Martin. Sein und Zeit. Berlin: De Gruyter, 2015. 
institutions a constitution creates or regulates to carry out the duties and discretionary authority delegated by the people. ${ }^{34}$

The distinction between amendments and dismemberments is democratically relevant due to its theoretical relation with the constituent power, which has been defined as the truth of modern Democracy ${ }^{35}$ or the juristic expression of the democratic impetus. $^{36}$

Can we consider democratically legitimate a constitutional amendment? What about a constitutional dismemberment? Richard Albert answers these questions (not explicitly) a contrario sensu by stating: "no constitution can properly be formed by a constituted power; it must be created-and understood to have been created - by the exercise of constituent power, which is to say by the people themselves."137

Therefore, theoretically no constitution can be dismantle, destroyed (that is dismembered) by a constituted power, only the exercise of constituent power, by the people themselves, can do so. This interpretation follows the words of the Declaration of Independence of the U.S.: "whenever any form of government becomes destructive of these ends, it is the right of the people to alter or to abolish it, and to institute new government" but on the Federal Constitution. This is an excellent point that forces a democratic role in constitutional control. A role that can be exercised directly through referenda, popular consultations or constitutional crowdsourcing.

Richard's theoretical explanation does not mention the classical distinction within the constituent power (pouvoir constituant originaire and pouvoir constituant derivé) that it has been used in order to "democratically legitimise" the role of constitutional/supreme courts as exclusive guardians of the constitution. The "original constituent power" does not derive its legitimacy from a pre-existing legal norm; it is in terms of Kelsen, the power that creates the basic norm without legal constrains. ${ }^{38}$ The "derived constituent power" is related to the amendment of the constitution, it must respect the procedure, and material constraints imposed by the constitution. Nevertheless, it stills been a constituent power, and therefore it can legitimately dismember the constitution.

These theories need to be updated to the new technological era, where e-democracy offers a new range of possibilities to implement and improve direct Democracy in the realm of the constituent power. We have observed (Iceland, Chile, Colombia,

\footnotetext{
34 ALBERT, Richard. Constitutional Amendments: Making, Changing and Breaking Constitutions. New York: Oxford Univ. Press, 2019. p. 72.

35 KALYVAS, Andreas. Constituent Power. In: BERSTEIN, Jay M.; OPHIR, Adi; STOLER, Ann Laura (eds.). Political Concepts, a Critical Lexicon. New York: Fordham University Press. Available at: <https://www.politicalconcepts.org/constituentpower/>.

36 See LOUGHLIN, Martin. The Idea of Public Law. Oxford: Oxford University Press, 2004.

37 ALBERT, Richard. Constitutional Amendments: Making, Changing and Breaking Constitutions. New York: Oxford Univ. Press, 2019. p. 72.

38 KELSEN, Hans. The Pure Theory of Law. Clark: The Lawbook Exchange, 2015.
} 
Catalonia, Ireland) the first experiences of people acting in the original constituent power directly. These experiences have overcame the limits and constraints of an imposed fiction supported by several theories that excluded the people as effective sovereign. From the "contractualism" (from Rousseau to Bell, Gaus), "consensual acceptance" (From Hume to Barnett), to the 'rule of recognition' (Hart, Green, Raz, Kutz). The truth modern democracy may now end with the invisibility of the people and fulfil the eternal promise of the modern constituent power, to make the people as-the-governed active participants in the shaping and ruling of political systems, and constitutional charters. $^{39}$

Whether the concept of constituent power is a sociological concept, neither moral nor legal it is contested. However, Loughlin locates the constituent power on the boundaries of legal knowledge, whose meaning is bound up with deeper disputes concerning the nature of legal, political and constitutional ordering..$^{40}$ Kalyvas and Nootens define the concept as political, due to its conceptual articulation with the concept of Democracy. ${ }^{41}$ Arato links the concept with other political notions (social contract, sovereignty, the people as a whole and the separation of powers). ${ }^{42}$

The debate on the nature of the constituent power is not merely theoretical. The point to establish a normative and not sociological concept is to legitimate legal change that cannot be legitimated with reference to existing legal norms. If the concept of constituent power is normative and justificatory, a constitutional dismemberment will be legitimate if it follows the legal processes (positivist approach). On the other hand, if it is sociological, the legitimation can be alegal, in a constitutional democracy, democratically.

\section{CONCLUSION}

Solon, a founder of Athenian Democracy, was an statesman, poet and legislator that governed Athens in a period of enormous social conflicts. The Solonian Constitution (politeia) introduced several measures to growth popular sovereignty, such as the cancellation of mortgages and indebtedness of the landholders' citizens; all debt-slaves

\footnotetext{
39 NOOTENS, Geneviève. Constituent power and people-as-the-governed: About the 'invisible' people of political and legal theory. Global Constitutionalism, vol. 4, n. 2, p. 137-156, 2015.

40 LOUGHLIN, Martin. The Idea of Public Law. Oxford: Oxford University Press, 2004.

${ }^{41}$ See KALYVAS, Andreas. Constituent Power. In: BERSTEIN, Jay M.; OPHIR, Adi; STOLER, Ann Laura (eds.). Political Concepts, a Critical Lexicon. New York: Fordham University Press. Available at: <https://www.politicalconcepts.org/constituentpower/>; NOOTENS, Geneviève. Constituent power and people-as-the-governed: About the 'invisible' people of political and legal theory. Global Constitutionalism, vol. 4, n. 2, p. 137-156, 2015.

42 ARATO, Andrew. The Adventures of the Constituent Power, beyond Revolutions? Cambridge: Cambridge University Press, 2017.
} 
were freed, he confirmed of the Ekklesia as source of all legislative, executive and judicial power, and opened the membership of the law courts to all. ${ }^{43}$

After ruling and reforming Athens, Solon travelled abroad for ten years, in a self-imposed exile visiting Egypt, Cyprus and Lydia. When he returned to Athens, he found a very different political situation; he could not recognise his city because of the political changes and upheavals that occurred. Some of the democratic measures that Solon introduced in the constitution were amended by the Jurors, taking advantage of the constitutional flexibility and the vague language of Athenian statues. ${ }^{44}$ The Athenian Constitution was an unentrenched written constitution because the body of standing laws could be amended at any time.

Despite Richard Albert states that it is a modern practice, political and constitutional amendments are old as constitutions (codified and uncodified) and political systems. Amendments and changes are intrinsic and unavoidable features of law. Law and constitutions are living documents and codified rules of change and formal amendments are guarantees and safeguards of legal certainty and the rule of law. Albert with this book, as he aimed, brings formal amendment back to centre of the field of constitutional change.

Multiple elements of his work are going to condition the constitutional analysis on constitutional amendments. His distinction between amendments and dismemberment fills a doctrinal loophole, which exists because of the widespread use of a concept (constitutional amendment). As Richard Albert claims the phenomenon of dismemberment has a different essence and transcendence, it is not a "mere" constitutional mutation but a make or a break that deserves an autonomous concept. In this sense, the cases of Making and Breaking of the title of the book may be dismemberments.

Albert's book is a comparative constitutional law tour de force, which deals mainly with constitutional change and control, but not only. Throughout this epistemological distinction, Richard convincingly opens the door to an approach of two domains (constitutionalism and Democracy) that are inevitably in tension. His proposal provides visibility to the people in the domain of constitutional change and helps to overcome an ancient scepticism on law, Democracy and a possible symbiotic coexistence.

\section{REFERENCES}

ABAT NINET, Antoni. Constitutional Violence, Legitimacy, Democracy and Human Rights. Edinburgh University Press, 2012.

43 ARISTOTLE. The Politics and the Constitution of Athens. Cambridge: Cambridge University Press, 1996.

44 ABAT NINET, Antoni. Constitutional Violence, Legitimacy, Democracy and Human Rights. Edinburgh University Press, 2012. 
ACKERMAN, Bruce. We the people Foundations. Cambridge: Harvard University Press, 1995.

ACKERMAN, Bruce; MATSUDAIRA, Tokujin. Dishonest Abe. Foreign Policy, 24 June 2014. Available at: <http://foreignpolicy.com/2014/06/24/dishonest-abe/>.

ALBERT, Richard. Constitutional Amendments: Making, Changing and Breaking Constitutions. New York: Oxford Univ. Press, 2019.

ARATO, Andrew. The Adventures of the Constituent Power, beyond Revolutions? Cambridge: Cambridge University Press, 2017.

ARISTOTLE. The Politics and the Constitution of Athens. Cambridge: Cambridge University Press, 1996.

CONCHE, Marcel. The Fragments of the Work of Heraclitus of Ephesus On Nature. London: Creative Media Partners, 2018.

COTA, Maurizio. Partitocracy: Parties and their Critics in Italian Political Life. In: PASQUINO, Jones, E., (eds.). The Oxford Handbook of Italian Politics. Oxford-New York: Oxford University Press, 2015.

DIEMERT, Stephane. L'histoire constitutionnelle de l'outre-mer sous la Ve République. Nouveaux Cahiers du Conseil Constitutionnel, Paris, n. 35, Dossier: La Constitution et I'Outre-Mer, avr. 2012. Available at: <https://www.conseil-constitutionnel.fr/nouveaux-cahiers-du-conseil-constitutionnel/l-histoire-constitutionnelle-de-I-outre-mer-sous-la-ve-republique>.

GALLOP, David. Parmenides of Elea: Fragments, a Text and Translation. Toronto: Toronto University Press, 1984.

GREY, Thomas. C. Origins of the Unwritten Constitution: Fundamental Law in American Revolutionary Thought. Stanford Law Review, vol. 30, n. 5, p. 843-893, 1978.

HEIDEGGER, Martin. Sein und Zeit. Berlin: De Gruyter, 2015.

HERZOG, Donald J. Democratic Credentials. Ethics, vol. 104, n. 3, p. 467-479, 1994.

KALYVAS, Andreas. Constituent Power. In: BERSTEIN, Jay M.; OPHIR, Adi; STOLER, Ann Laura (eds.). Political Concepts, a Critical Lexicon. New York: Fordham University Press. Available at: <https:// www.politicalconcepts.org/constituentpower/>.

KELSEN, Hans. The Pure Theory of Law. Clark: The Lawbook Exchange, 2015.

LOUGHLIN, Martin. The Idea of Public Law. Oxford: Oxford University Press, 2004.

NOOTENS, Geneviève. Constituent power and people-as-the-governed: About the 'invisible' people of political and legal theory. Global Constitutionalism, vol. 4, n. 2, p. 137-156, 2015.

RICOEUR, Paul. Événement et sens. Raisons practiques, vol. 2, p. 41-56, 1991. 
ROZNAI, Yaniv. Unconstitutional Constitutional Amendments: The Limits of Amendment Powers. Oxford: Oxford University Press, 2017.

SCHEPELLE, Kim Lane. Aspirational and Aversive constitutionalism: The case for studying cros$s$-constitutional influence through negative models. International Journal of Constitutional Law, vol. 1, n. 2, p. 296-324, 2003.

STRAUSS, David. A. The irrelevance of constitutional amendments. Harvard Law Review, vol. 114, p. 1457-1505, 2001.

TUSHNET, Mark. Peasants with Pitchforks, and Toilers with Twitter: Constitutional Revolutions and the Constituent Power. International Journal of Constitutional Law, vol. 13, n. 3, p. 639-654, 2015. 